\title{
Breast cancer in Jalisco: a spatial analysis of mortality in the 2010-2017 period
}

\author{
Igor M. Ramos-Herrera, ${ }^{1}$ Antonio Reyna-Sevilla, ${ }^{1 *}$ Miguel E. González-Castañeda, ${ }^{2}$ \\ Juan D. Robles-Pastrana, ${ }^{2}$ Dulce D. Herrera-Echauri and César A. González-Rivera ${ }^{2}$ \\ ${ }^{1}$ University Center of Health Sciences, ${ }^{2}$ University Center for Social Sciences and Humanities, Universidad de Guadalajara, Jalisco, Mexico
}

\begin{abstract}
Introduction: In 2017, INEGI reported 84,142 deaths from malignant tumors in Mexico, while the World Health Organization indicated that the breast cancer mortality rate in 2018 was 11.2 per 100,000 women. Objective: To show the trend of breast cancer mortality in women by municipality and health region of Jalisco in the 2010-2017 period. Method: Analytical study in which standardized mortality rates and relative risks of 3873 women were estimated by municipality of residence. Dispersion and central tendency spatial statistics were used. Results: The mortality rate increased from 10.7 to 13.0 per 100,000 women in the 2010-2017 period. The highest values were found in the municipalities of Chapala (21.2) and Guadalajara (19.5); the mortality rate increased in four out of every 10 municipalities, and relative risk was up to 50-fold higher in some of the western and central Jalisco municipalities. Conclusions: An annual increase of $1.0 \%$ was observed, although it was territorially differentiated. The results represent an opportunity to improve timely detection and diagnostic processes, as well as to guarantee the coverage of services.
\end{abstract}

KEY WORDS: Breast neoplasms. Relative risk. Mortality records. Geographical risk location.

\section{Cáncer de mama en Jalisco. Análisis espacial de la mortalidad en 2010-2017}

\section{Resumen}

Introducción: En 2017, el INEGI reportó 84142 defunciones por tumores malignos en México y la Organización Mundial de la Salud indicó que la tasa de mortalidad por cáncer de mama en 2018 fue de 11.2 por 100 mil mujeres. Objetivo: Mostrar la tendencia de la mortalidad por cáncer de mama en mujeres según municipio y región sanitaria de Jalisco en el periodo 2010-2017. Método: Estudio analítico en el que se estimaron tasas estandarizadas de mortalidad y riesgos relativos por municipio de residencia de 3873 mujeres. Se utilizó estadística espacial de dispersión y tendencia central. Resultados: La tasa de mortalidad aumentó de 10.7 a 13.0 por 100 mil mujeres en el periodo 2010-2017. Los valores más altos se encontraron en los municipios de Chapala (21.2) y Guadalajara (19.5), la tasa de mortalidad aumentó en cuatro de cada 10 municipios y el riesgo relativo fue hasta 50 veces mayor en algunos del occidente y centro de Jalisco. Conclusiones: Se observó un incremento de $1.0 \%$ anual, aunque territorialmente diferenciado. Los resultados representan una oportunidad para mejorar los procesos de detección y diagnóstico oportunos, así como para garantizar la cobertura de los servicios.

PALABRAS CLAVE: Neoplasias de mama. Riesgo relativo. Registros de mortalidad. Localización geográfica de riesgo.

Correspondence:

*Antonio Reyna-Sevilla

E-mail: gs.antonioreyna @gmail.com
Gac Med Mex. 2020;156:532-538

Contents available at PubMed

www.gacetamedicademexico.com

0016-3813/@ 2020 Academia Nacional de Medicina de México, A.C.. Published by Permanyer. This is an open access article under the CC BY-NC-ND license (http://creativecommons.org/licenses/by-nc-nd/4.0/). 


\section{Introduction}

One of the biggest challenges in terms of public health in Mexico are chronic-degenerative diseases, such as neoplasms. ${ }^{1,2}$ In 2017, according to the National Institute of Statistics and Geography (INEGI Instituto Nacional de Geografía y Estadística), 84,142 deaths were attributed to malignant tumors, i.e., $12 \%$ mortality in the general population. ${ }^{3}$ Among them, breast cancer (BC) in Mexican women represents the most common cause of death since 2006. ${ }^{1,4}$ In part, this could be explained by the number of diagnoses carried out every year; up to four out of every 10 cases in women between 30 and 50 years of age turn out to be BC. ${ }^{5}$ In addition, the Pan American Health Organization indicates that, in 2018, the $\mathrm{BC}$ mortality rate in Mexico was 11.2 per 100,000 women, ${ }^{6}$ which certainly represents a significant decrease with regard to that reported in 2012: 17.1 deaths per 100,000 women. ${ }^{7}$ However, even with the efforts to reduce such magnitude, which some authors attribute to improvements in diagnostic processes or access to cancer treatment, ${ }^{2}$ most cases in Mexico are diagnosed at advanced stages (II-b to IV clinical stages), ${ }^{8-10}$ with differences between states or municipalities, which increases the risk of BC mortality in women. ${ }^{8,11}$

This epidemiological outlook has promoted, among other things, the development of research focused on determining the magnitude and trends of $B C$ in Mexico, but to a lesser extent on addressing geographical variations and mortality focalization. There are known epidemiological studies that include the analysis of data corresponding to long periods, for example, between seven and 31 years, ${ }^{2,5,12-17}$ developed in the states $^{5,13-15,18}$ or municipalities, ${ }^{13}$ although not all related to $\mathrm{BC}$. Among the main contributions of these investigations, updated estimates on mortality, evaluation of advances in prevention, detection and treatment services established in NOM-041-SSA2-2011 stand out, ${ }^{19}$ as well as the determination of these aspects' intervention and improvement needs. ${ }^{2,5}$

However, there are significantly fewer analyses that incorporate a territorial perspective, for example, to recognize the distribution and variation of spatial patterns associated with $\mathrm{BC}$, to identify places where anticipating and guaranteeing health services coverage for women at risk of suffering from it is required, or else, to focalize secondary prevention actions, ${ }^{20}$ as established by NOM-041-SSA2-2011, ${ }^{19}$ and thereby improve the processes involved in early detection, timely diagnosis and specialized treatments.

In this sense, spatial epidemiology, which includes a territorial perspective among its analytical tools, can contribute to generate complementary evidence to studies on BC mortality trends by analyzing the spatial-temporal distribution of diseases or death causes, mapping places with higher risk or identifying patterns at different territorial scales. ${ }^{21,22}$ This aspect is highly important for supporting decision-making ${ }^{22}$ and allocation of resources (material and human) associated with secondary prevention, ${ }^{14}$ in order to, ultimately, reduce health inequalities. ${ }^{22}$

\section{Objective}

To show, from a spatial approach to epidemiology and public health, the spatial-temporal trend of the risk Jalisco's women have for dying from BC in recent years, as well as to analyze mortality rates geographic differences by municipality and health region of the state during the 2010-2017 period.

\section{Method}

An analytical, cross-sectional-design study was used, given the secondary source consulted for obtaining the data and their grouping in geographic areas for analysis and comparison. In the first stage, 2010 to 2017 mortality statistics related to BC in women according to municipality of residence were obtained from the Jalisco Ministry of Health State Cancer Registry. Said data were georeferenced considering all 125 municipalities of Jalisco, according to INEGl's National Geostatistical Framework, ${ }^{23}$ as well as the 13 health regions that make up said territorial demarcation, according to official data from that Ministry.

Based on the georeferenced data, a second stage involved estimating mortality rates, standardized by municipality and year. ${ }^{24}$ For that, the empirical Bayes smoothing method was used in order to avoid a spurious representation in the magnitude and geographic distribution of rates, whose effect is produced by differences in the population size according to the spatial unit of analysis that was used (municipality). ${ }^{24}$ For this calculation, official projections of the female population older than 20 years by municipality were used through the General Directorate of Health Information Dynamic Cubes tool. ${ }^{25}$ In addition, other indicators were estimated for $\mathrm{BC}$ mortality analysis: relative risk and increase ratio (IR) between 2010 and 2017; both 
were represented on maps by municipality and health region.

In a third stage, standardized mortality rate variability and trend (increase or decrease) were estimated by linear regression. In addition, to identify the magnitude and geographic differences of the calculated rates, spatial statistics were used, i.e., measures of dispersion, central and directional tendency (standard deviation ellipse) were obtained in order to determine in which municipalities did the highest values concentrate, which were the ones that recorded an increase or decrease from 2010 to 2017, and to define areas with higher $\mathrm{BC}$ mortality risk.

\section{Results}

In Jalisco, depending on the source that was resorted to, there were $3,873 \mathrm{BC}$ deaths recorded from 2010 to 2017 , reported only in 119 municipalities (95.2\%), which translates into a crude rate of 12.2 per 100,000 women older than 20 years. Figure 1 shows the linear regression analysis, where an ascending trend in $B C$-related deaths stands out ( $p<0.05)$; in addition, a total increase of $17 \%$ was identified according to the mortality rate for 2010-2017.

On the other hand, in figure 2 , the magnitude and geographic distribution of the mortality rate according to municipality of residence at the time of death (20102017) can be observed, with values ranging from 5.3 to 21.2 per 100,000 women older than 20 years of age. As result, the municipalities of Chapala and Guadalajara showed a standardized rate up to two times higher than municipal average (upper outliers): 21.2 and 19.5 deaths per 100,000 women older than 20 years, respectively. These municipalities belong to the La Barca and Guadalajara health regions, located at the state central area.

The map in figure 3 shows mortality rate geographic variability between 2010 and 2017 by municipality and health region (IR); as a result, it can be observed that, in 68 municipalities (54.4\%), mortality decreased, in another seven municipalities (5.6\%), there was no change, while mortality increased up to 90 times in the remaining 50 municipalities (40\%); the latter was mainly recorded in central health regions (Zapopan, Guadalajara, Tonalá) and in Jalisco northeast areas (Tepatitlán, Lagos de Moreno).

By estimating BC mortality RR according to the area of residence (Fig. 4), 50 municipalities (40\%) were identified where said indicator was $>1$, but RR increased more than 50 times particularly in 12

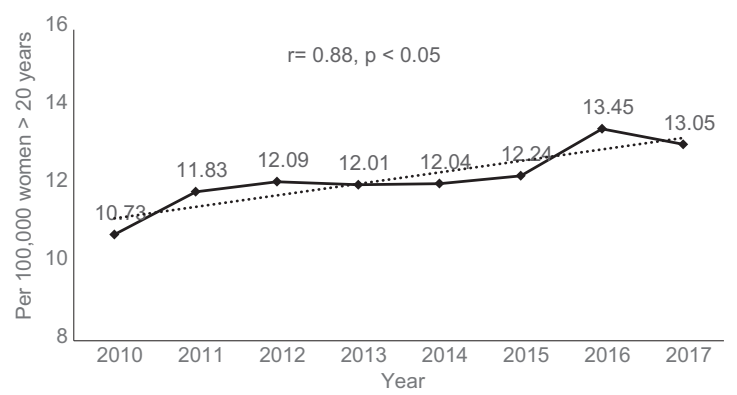

Figure 1. Standardized breast cancer mortality rate trend in Jalisco, 2010-2017. Source: own creation based on Jalisco Ministry of Health women breast cancer mortality statistics.

municipalities (9.6\%). These results can be observed in the map in figure 4, from the western area (Health Region VIII-Puerto Vallarta North Coast) towards northeast Jalisco (Health Region III-Tepatitlán), which forms a strip that transversely crosses the entire state. Moreover, analysis using the standard deviation ellipse corroborates this spatial trend (Fig. 5), which indicates the area where $\mathrm{BC}$ mortality rate was higher in comparison with other municipalities; in fact, this delimitation explains $83.6 \%(n=3,240)$ of the deaths recorded in the study period (isoconcentration). Additionally, in figure 5 map, the spatial trend results can be observed, which implies a delimitation associated with low and high BC mortality, regardless of political-administrative boundaries (municipalities and health regions) in Jalisco, with a southwest-northeast orientation.

\section{Discussion}

Between 2010 and 2017, BC mortality in Jalisco increased by $17 \%$. However, only in four out of every 10 municipalities was this trend observed, with its location being identified from the west towards the center of the state, where RR increased up to $50 \%$. Thus, we consider that BC mortality concentration and dispersion represents an opportunity to recognize municipalities where improving detection timely processes and clinical diagnosis is required, as established by NOM-041-SSA2-2011, ${ }^{19}$ given that they constitute foci that explain mortality in certain contexts ${ }^{8,10}$ where greater proximity to $\mathrm{BC}$ diagnostic and treatment services may exist.

Even though the World Health Organization reported a decrease in BC mortality in Mexican women, an actual increase has recently become evident. 2,10,12,13,15-17 For example, from 1990 to 2013, mortality increased 


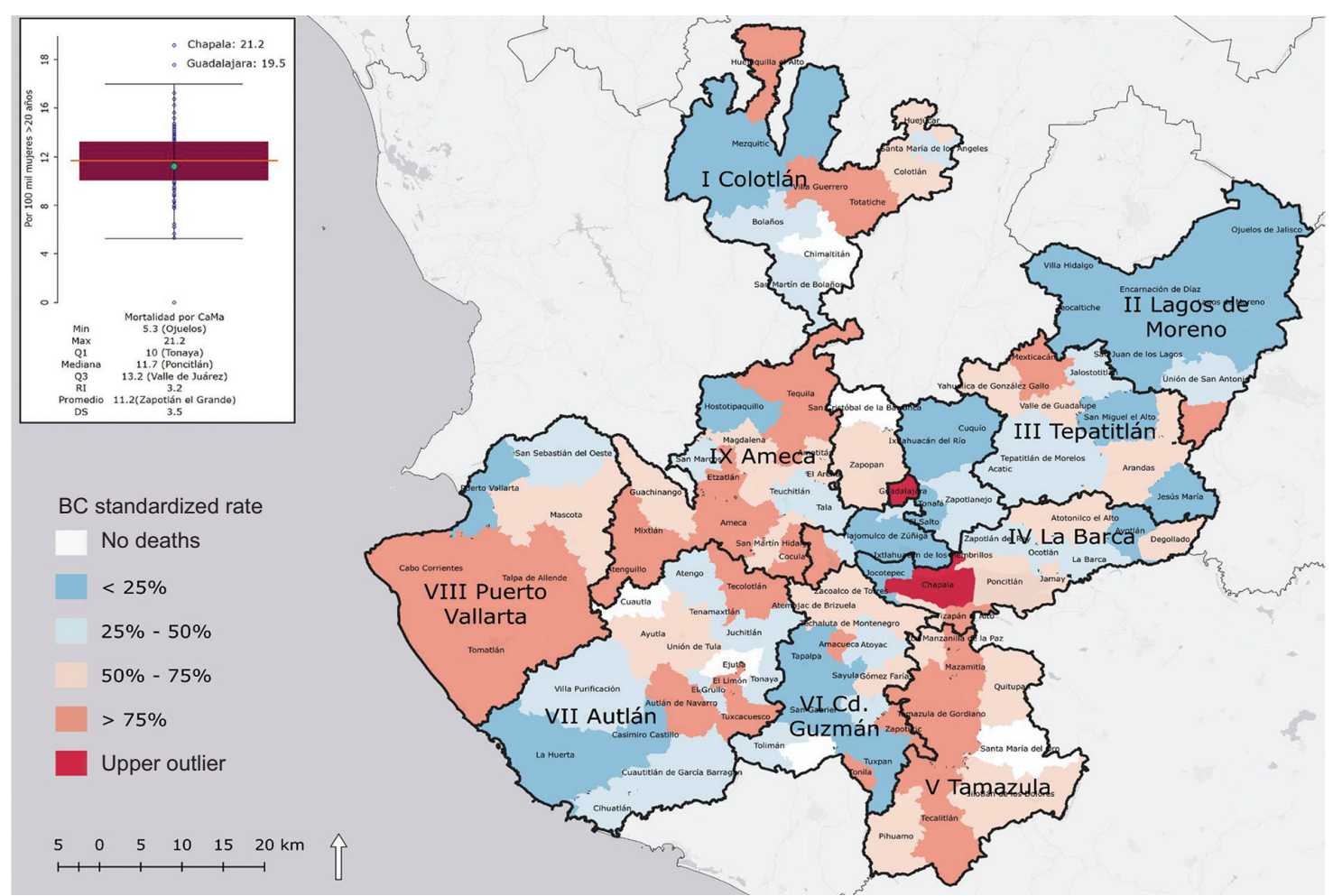

Figure 2. Breast cancer standardized mortality rate magnitude and geographical distribution according to municipality of residence, Jalisco $2010-$ 2017. Source: Own creation based on vital statistics on breast cancer mortality in women covered by Jalisco Ministry of Health, as well as based on Jalisco State and Municipal Geostatistical Framework. ${ }^{23}$

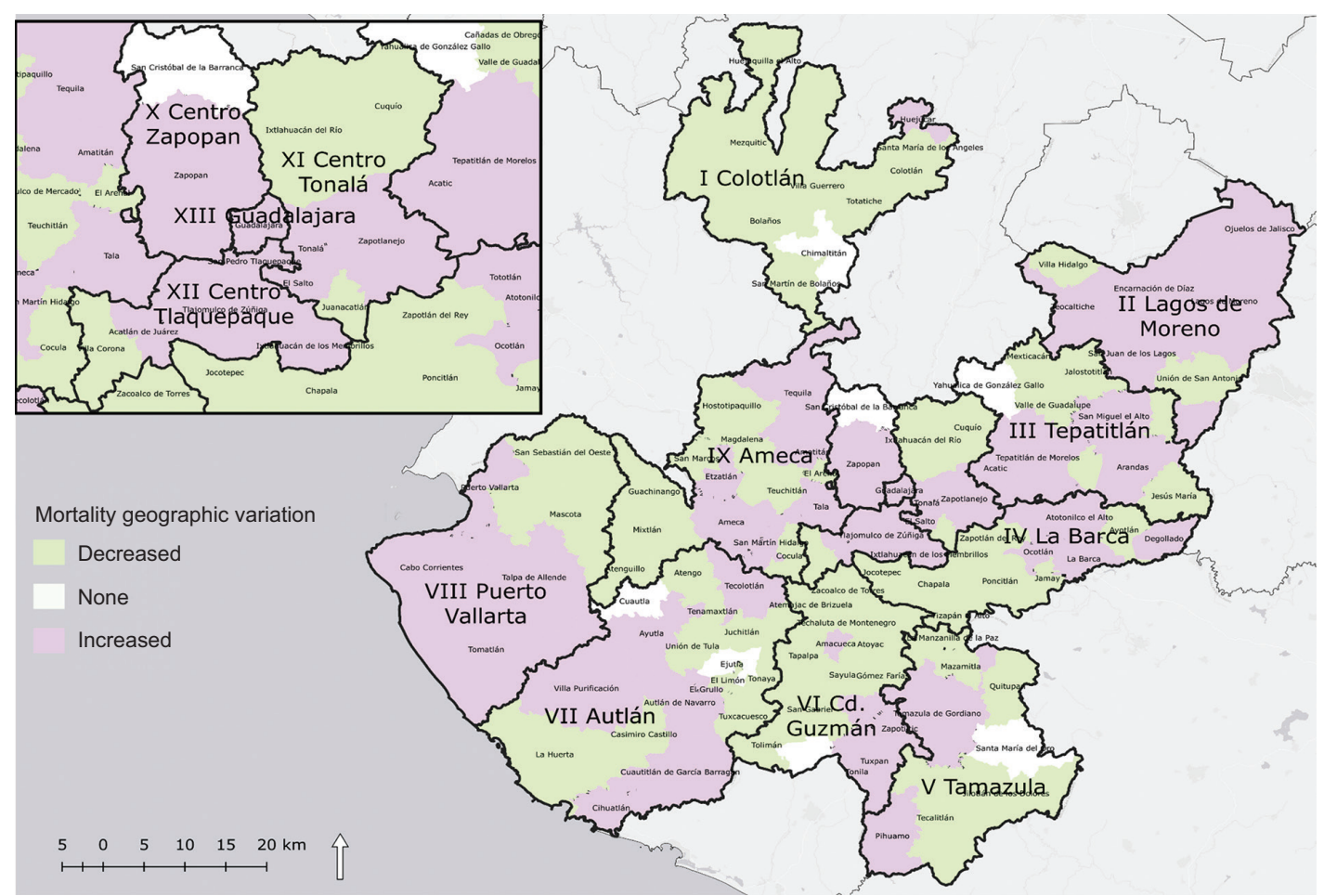

Figure 3. Breast cancer mortality increase geographic variation between 2010 and 2017 according to municipality of residence, Jalisco. Source: Own creation based on vital statistics on breast cancer mortality in women covered by Jalisco Ministry of Health, as well as based on Jalisco State and Municipal Geostatistical Framework. ${ }^{23}$ 


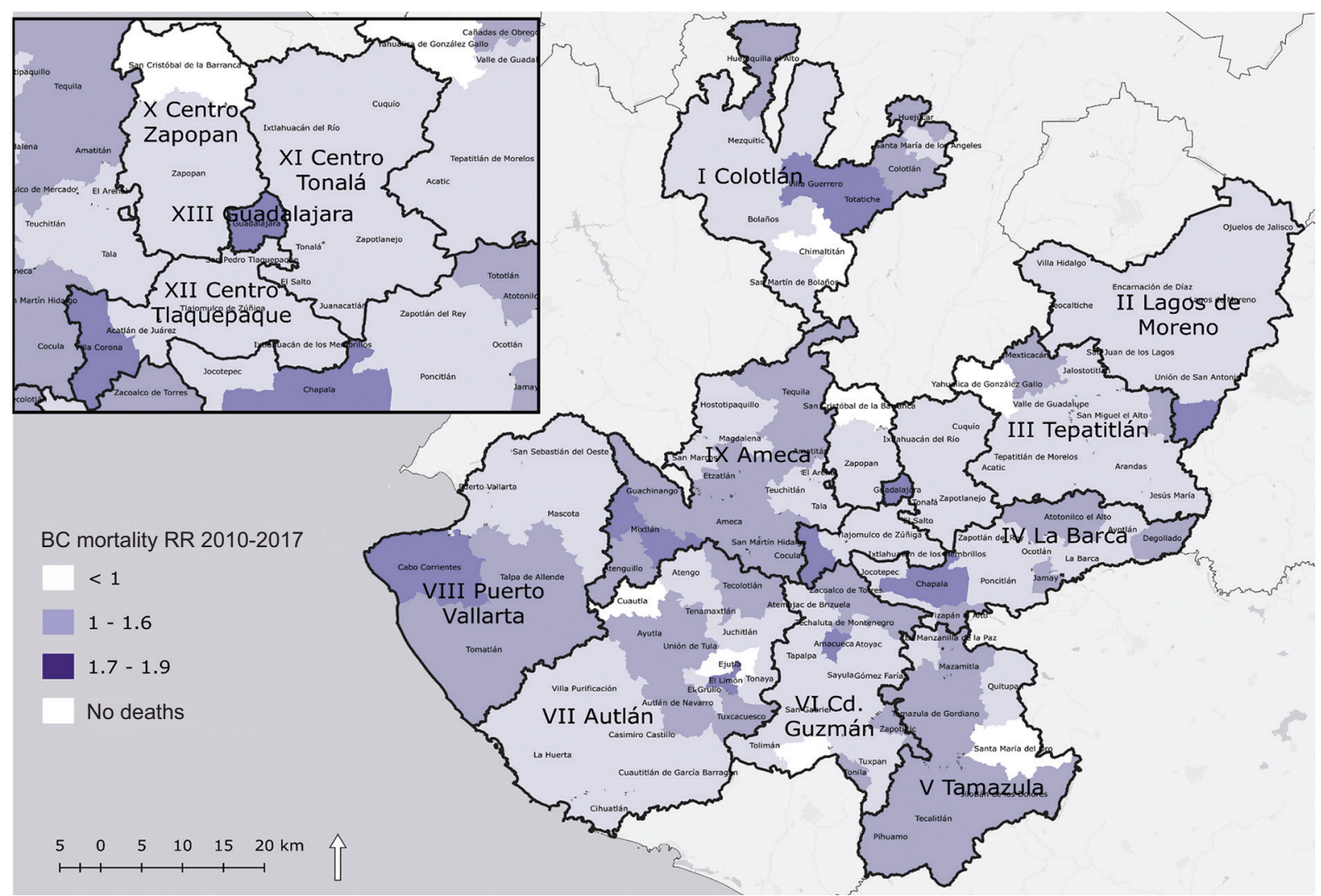

Figure 4. Breast cancer mortality relative risk geographic distribution according to municipality of residence, Jalisco 2010-2017. Source: Own creation based on vital statistics on breast cancer mortality in women covered by Jalisco Ministry of Health, as well as based on Jalisco State and Municipal Geostatistical Framework. 23

by $15 \%$ in Jalisco, ${ }^{5}$ which has even been one of the states with the highest rates in comparison with others of the Mexican Republic..$^{15}$ Thus, said outlook is consistent with the results herein reported, even though free care and optimal treatments at all stages of BC has been offered since 2007 as part of the Seguro Popular (People's Health Insurance) Catastrophic Expenditure program. ${ }^{8}$ For this reason, we consider that the mortality increase in Jalisco might be related to deficiencies in BC detection and clinical diagnosis, coupled with a low response of women to BC preventive programs, ${ }^{12}$ or to a higher availability of and access to health services, ${ }^{2,13}$ beyond known risks factors. ${ }^{5,8}$

The National Health and Nutrition Survey ${ }^{26}$ reported in Jalisco one of the lowest mammography coverages -as an early detection method- of the country, $29.3 \%$ lower in comparison with northern states, where the proportion of women who undergo the screening test was four out of every $10 .{ }^{26}$ Therefore, it is to be assumed that clinical stage at the time dignosis is made is at advanced phases of the disease (stages Ilb to IV), as it occurs in other states of Mexico, ${ }^{8-10}$ which limits prognosis and survival probabilities. ${ }^{4}$ Thus, it is possible to assume that clinical stage and the detection process might explain the magnitude of $\mathrm{BC}$ mortality reported in Jalisco in recent years. ${ }^{12}$ According to Roche, Skinner \& Weinstein, ${ }^{11}$ diagnoses at advanced stages are a consequence of the low effectiveness of actions aimed at early detecting the disease. Therefore, our results define, in principle, Chapala and Guadalajara as the municipalities where evaluating actions aimed at preventing, detecting and offering specialized treatment to reduce the burden of $\mathrm{BC}$ mortality is required.

One of the most effective strategies for $\mathrm{BC}$ control and epidemiological surveillance, according to the world report on cancer, is secondary prevention, which refers to detecting the disease at premalignant stages. ${ }^{20}$ In this sense, our results could serve as a basis for organizing detection programs, improving diagnostic processes and ensuring timely treatment, as established by NOM-041-SSA2-2011, ${ }^{19}$ in municipalities from Jalisco's west to central areas at higher risk. This, in order to minimize BC mortality-related 


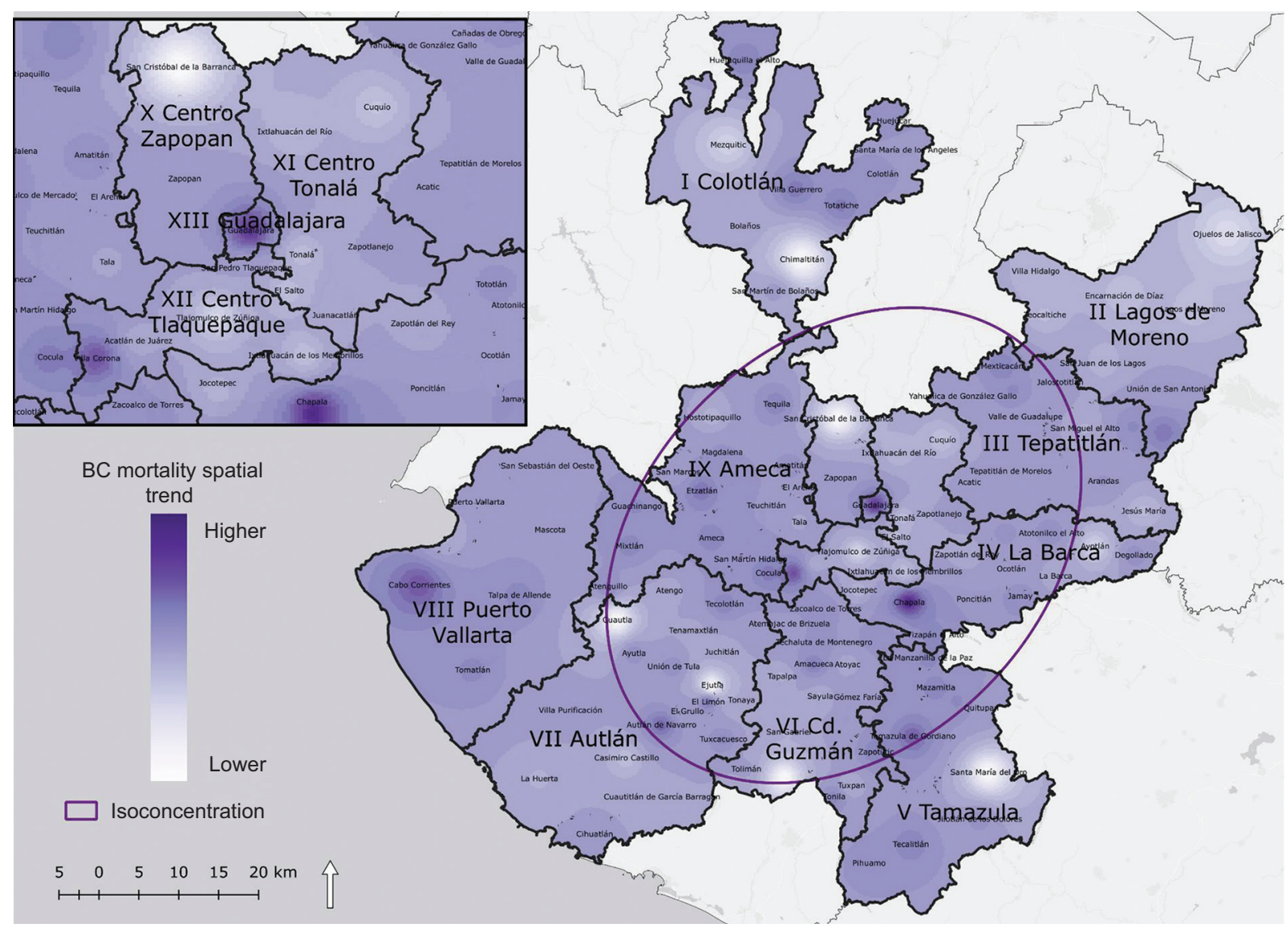

Figure 5. Breast cancer mortality spatial trend in the context of Jalisco municipalities and health regions. Source: Own creation based on vital statistics on BC mortality in women covered by Jalisco Ministry of Health, as well as based on Jalisco State and Municipal Geostatistical Framework. $^{23}$

problems, such as delay in diagnosis and cancer treatment initiation, or else, geographic inequalities.

On the other hand, it is necessary to consider some limitations related to the use of data from a secondary source, where there might be underreporting of the analyzed deaths, although the quality in death registration has significantly improved in Mexico in recent years. ${ }^{2}$ In fact, the presented information can serve to elucidate the challenge that is faced by the Jalisco Ministry of Health around $\mathrm{BC}$ mortality magnitude and variability in municipalities, coupled with the financial burden implied by diagnosis and treatment. Another limitation lies in the analysis of retrospective data from several years, the interpretation of which should therefore be made with caution.

In conclusion, we highlight three important aspects:

- First, municipalities were identified where mortality increased in the 2010-2017 period (40\%), from central to northeastern Jalisco, where evaluating the processes involved in prevention, detection, clinical diagnosis and availability of specialized treatments is suggested.
- Second, from the west to the center, municipalities were identified $(9.6 \%)$ where mammography services need to be promoted with greater emphasis in order to early detect the disease, since, depending on the area of residence, $R R$ increased up to 50 times.

- Finally, through the use of georeferenced data and geographic tools, risk or priority areas were identified where attention is required in order to tackle inequalities in women's care.

\section{Acknowledgements}

The authors thank the officials of the Jalisco Ministry of Health for providing the necessary data for the research.

\section{Conflicts of interest}

The authors declare that they have no conflicts of interest. 


\section{Funding}

The authors did not receive any sponsoring to carry out this article.

\section{Ethical disclosures}

Protection of human and animal subjects. The authors declare that no experiments were performed on humans or animals for this investigation.

Confidentiality of data. The authors declare that no patient data appear in this article.

Right to privacy and informed consent. The authors declare that no patient data appear in this article.

\section{References}

1. Lozano R, Gómez H, Pelcastre B, Ruelas M, Montañez J, Campuzano J, et al. Carga de la enfermedad en México, 1990-2010. Nuevos resultados y desafíos. Mexico: Centro de Investigación en Sistemas de Salud; 2013.

2. Torres-Sánchez LE, Rojas-Martínez R, Escamilla-Núñez C, de la Vara-Salazar E, Lazcano-Ponce E. Tendencias en la mortalidad por cáncer en México de 1980 a 2011. Salud Publica Mex. 2014;56:473-491.

3. Instituto Nacional de Estadística y Geografía [website]. Mexico: Estadísticas a propósito del Día Mundial contra el Cáncer (4 de febrero). Datos nacionales. [Press release]; 2018.

4. De la Vara-Salazar E, Suárez-López L, Ángeles-Llerenas A, Torres-Mejía G, Lazcano-Ponce E. Mortalidad por cáncer de mama en México: niveles, evolución y tendencias 1980-2009. In: Lazcano-Ponce E, Escudero-de los Ríos $\mathrm{P}$, Uscanga-Sánchez $\mathrm{S}$, editors. Cáncer de mama. Diagnóstico, tratamiento, prevención y control. Mexico: Instituto Nacional de Salud Pública; 2014.

5. Gómez-Dantés H, Lamadrid-Figueroa H, Cahuana-Héctor L, Silverman-Retana O, Montero P, González-Robledo MC, et al. The burden of cancer in México, 1990-2013. Salud Publica Mex. 2016:58(2):118-131.

6. Organización Panamericana de la Salud [website]. USA: Situación de salud en las Américas: indicadores básicos; 2018.

7. Centro Nacional de Equidad de Género y Salud Reproductiva. Programa de acción específico. Prevención y control del cáncer de la mujer 20132018. Mexico: Secretaría de Salud; 2014.
8. Cárdenas-Sánchez J, Erazo-Valle Solís AA, Arce-Salinas C, Bargalló-Rocha JE, Bautista-Piña V, Cervantes-Sánchez G, et al., editors. Consenso mexicano sobre diagnóstico y tratamiento del cáncer mamario. Mexico: Elsevier. 2017.

9. Maffuz-Aziz A, Labastida-Almendaro S, Espejo-Fonseca A, Rodríguez-Cuevas S. Características clinicopatológicas del cáncer de mama en una población de mujeres en México. Cir Ciruj. 2017;85:201-207.

10. Chávarri-Guerra Y, Villarreal-Garza C, Liedke PER, Knaul F, Mohar A, Finkelstein DM, et al. Breast cancer in Mexico: a growing challenge to health and the health system. Lancet Oncol. 2012;13:e335-e343.

11. Roche LM, Skinner R, Weinstein RB. Use of a geographic information system to identify and characterize areas with high proportions of distant stage breast cancer. J Public Heal Manag Pract. 2002;8:26-32.

12. Ramos-Herrera I, González-Castañeda E, Reyna-Sevilla A, Robles-Pastrana JD, García-Sandoval C. Mortalidad por cáncer de mama en Jalisco: un análisis espacio temporal a nivel municipal. UniverSalud. 2016;12:37-54.

13. Aguayo AG, Jiménez PL, Celis RA, Canales MJ. Mortalidad por cáncer de mama. Tendencia y distribución geográfica, 1981-2001. Rev Med Inst Mex Seguro Soc. 2008;46:367-374.

14. Palacio ML, Lazcano PE, Allen LB, Hernández AM. Diferencias regionales en la mortalidad por cáncer de mama y cérvix en México entre 1979 y 2006. Salud Publica Mex. 2009;51:208-219.

15. De la Vara-Salazar E, Suárez-López L, Ángeles-Llerenas A, Torres-Mejía G, Lazcano-Pone E. Tendencias de la mortalidad por cáncer de mama en México, 1980-2009. Salud Publica Mex. 2011;53:385-393.

16. Anaya RM, Vallejo RV, Flores ML, Pérez SM. Female breast cancer incidence and mortality in Mexico, 2000-2010. Asian Pac J Cancer Prev. $2014 ; 15: 1477-1479$

17. Bosetti C, Rodríguez T, Chatenoud L, Bertuccio P, Levi F, Negri E, et al. Trends in cancer mortality in Mexico, 1981-2007. Eur J Cancer Prev. 2011;20:355-363.

18. Navarrete-Valero $C$, Navarrete-Vázquez C. Mortalidad por cáncer mamario, prostático y cervicouterino, años perdidos y costos de los programas. México, 2013 a 2016. Gac Med Mex. 2018;154:665-670.

19. Norma Oficial Mexicana NOM-041-SSA2-2011 para la prevención, diagnóstico, tratamiento, control y vigilancia epidemiológica del cáncer de mama. Mexico: Diario Oficial de la Federación; 2011.

20. Stewart BW, Wild CW. World Cancer Report 2014. USA: World Health Organization; 2014.

21. Roquette R, Painho M, Nunes B. Spatial epidemiology of cancer: a review of data sources, methods and risk factors. Geospat Health. 2017:12:504.

22. Kirby RS, Delmelle E, Eberth JM. Advances in spatial epidemiology and geographic information systems. Ann Epidemiol. 2017;27:1-9.

23. Instituto Nacional de Estadística y Geografía [website]. Mexico: Marco geoestadístico, June; 2018.

24. Center for Spatial Data Science [website]. Illinois, Chicago: GeoDa: an introduction to Spatial Data Analysis; 2018.

25. Secretaría de Salud [website]. Mexico: Dirección General de Información en Salud. Población. Cubos Dinámicos; 2019.

26. Instituto Nacional de Salud Pública. Encuesta Nacional de Salud y Nutrición 2012. Resultados Nacionales. Síntesis ejecutiva. Mexico: Instituto Nacional de Salud Pública; 2012. 